\title{
The Elementary Forms of CARnival: Collective EfFervescence in Ger- MANY'S RHINELAND
}

YvonNe NieKRENZ

\begin{abstract}
Carnival is a cyclical, recurrent festival in Germany's Rhineland with several million revellers every year. This article explores the annual collective effervescence and asks how an entire region is turned "upside-down" for six days. Based on an ethnographic study focusing on street carnival, this analysis investigates the structuring frames of the festivity. Time and space limits and an altered presentation of the body play an important role in this ritual festivity. Carnival as a Rhenish corroboree consolidates group solidarity and affirms the imagined entity of society. Carnival is chaos and order, sacred and profane, and represents happiness as well as melancholy. The article argues that events like carnival are a chance to face up to ambivalence, an elementary experience of today's social world.
\end{abstract}

Keywords: carnival, effervescence, Durkheim, Maffesoli

Résume. Le carnaval est une fête cyclique à laquelle participent en Rhénanie plusieurs millions de fêtards chaque année. Cet article examine le phénomène d'effervescence collective que représente cet événement populaire mettant une région entière «sens dessus dessous» pendant six jours. En s'appuyant sur une étude ethnographique du carnaval de rue, il analyse le cadre structurel de ces festivités. Tant des limites temporelles et spatiales que la mise en scène de corps transformés jouent un rôle important dans cette fête rituelle. Le carnaval comme forme rhénane du corroboree consolide la solidarité de groupe et affirme l'unité imaginée de la société. Le carnaval, c'est l'ordre et le chaos, le sacré et le profane, la représentation de la félicité et de la mélancolie. Cet article argumente que des événements populaires comme le carnaval constituent une opportunité pour faire face à l'expérience élémentaire de l'ambivalence, caractéristique de la société contemporaine.

Mots clés: carnaval, effervescence, Durkheim, Maffesoli 


\section{INTRODUCTION}

M en dress up as women, children collect candies from the streets, administrative agencies and shops are closed all day, beer-soaked revellers toast each other, and people dance, sing, celebrate and enjoy themselves everywhere. What sounds like a "Pride Parade" (in Germany: Christopher Street Day), takes place in Germany's winterly Rhineland. This region is a carnival stronghold, where every year during the six days before Ash Wednesday, the world is turned upside down. Rooted in Catholicism, carnival is an annual event with several million visitors and tourists. It is a calendar festival preceding Christian Lent, dating back to the Middle Ages, where the hedonistic idea of immoderate eating, drinking, and dancing before the ascetic Lenten period was born. The Catholic pre-Lent festival has been historically documented as early as in the thirteenth century (Schwedt 1999: 63). Being the last opportunity to celebrate and feast, it was used to consume perishable food, or even to marry, prior to the start of Lent, a time characterized by self-denial, asceticism and a strict rule of abstinence. In a now more secularised world, the historical and Christian roots of Rhenish carnival have been fading into the background and the rhythm of hedonism and asceticism is practiced with more subtlety.

Why is this traditional festival still celebrated? Even today the cyclical festivity with its effervescence, irrationality, and liminality makes everyday life so much more worth living. Like a Rhenish "corroboree" (Durkheim 1995 [1912]: 217), carnival sets the ordinary conditions of life aside and constitutes an effervescent social environment. "By compressing itself almost entirely into circumscribed periods", Durkheim states, "collective life could attain its maximum intensity and power, thereby giving man a more vivid sense of the twofold existence he leads" (ibid.: 221). He hints here at the dualism of human nature (Durkheim 2005). In these states of collective effervescence, societies validate and revitalize themselves. As Durkheim argues in The Elementary Forms of Religious Life (hereafter EFRL), it is not just the simpler Australian societies that need a renewal of collective feelings; modern societies, too, must be open to this. Rites and the resulting collective feelings reinforce group solidarity and community, sustaining the imagined entity and unity of society. Carnivalesque rituals, customs, and practices constitute a sense of belonging, creating collective identity and symbols of community.

This paper considers: (1) the conditions of possibility of collective carnivalesque effervescence; (2) the categories of time, space, and body and; (3) the ambivalence designating events like carnival. Empirically, this article explores the annual carnivalesque frenzy based on an ethno- 
graphic study of Rhenish carnival conducted in 2007 and 2008. It considers how it is possible that every year an entire region is put into a state of collective effervescence. In doing so, this paper describes the carnivalesque world and the process by which its rules are constituted. I argue that defined space and time limits and resurrected rituals are structuring frames, inducing euphoria, while also absorbing chaotic power. I interpret the empirical data using Durkheim's concepts together with those of Michel Maffesoli, who has been holding the chair of sociology at the University of Paris "René Descartes" (Paris V - Sorbonne) since 1981. This is the prestigious chair Émile Durkheim held.

Carnival is an ambivalent event: it stands for order and chaos, vitality and transience, diversity and unity, individualization and collectiveness, happiness and melancholy, the sacred and the profane. "Ambivalence" is shown to be an elementary experience of today's social world, and carnival is argued to be an occasion to face up to this experience. The following description and analysis of rituals during Rhenish carnival is guided by the categories of space, time, and body, because rituals depend on bodily co-presence. Together they constitute the elementary forms of carnival which are both sacred and profane. Carnival can be seen as "sacred" because of its emphasis on feelings and irrationality, on the importance of community, rites and social practices in contrast to the "profane" (or mundane) elements of everyday life characterised by rational planning, exact regulation, and economic interests. The piece is organised as follows: first, cyclical festivities are described as "extraordinary realities", and their elementary structure is explored through a review of major theoretical statements. This is followed by an analysis of Rhenish carnival, including its historical origins and most important current customs. Next is a methodological discussion. The results of the research are then explicated in terms of the formation of the "life-world" of carnival. Finally, in the conclusion, the elementary forms of carnival are distilled.

\section{Rituals of Extraordinary Realities}

Cyclical festivities are planned events with the aim of creating unique experiences that break through the routines of everyday life, generating a sense of community among participants. For Durkheim, a shared mood and a feeling of well-being have to be created to constitute collective effervescence, with an intensified relationship between the individuals. As he states, "The very act of congregation is an exceptionally powerful stimulant" (1995: 219). During periods of social concentration, a feeling 
of the social whole emerges from such congregating. Collective effervescence leads to outlandish behaviour and even ecstatic states that are far removed from the ordinary conditions of life (ibid.: 218). Rituals play a crucial role: they are forms of communication that reduce the distance between people in a body, space and time conglomerate, thereby making sociality a sensual experience. Neither the past nor the future is important for people in these situations. All that counts is the present - the here and now - in which participants celebrate themselves in bodily co-presence. These temporary relations link people in space and time. Feelings of solidarity emphasize the group and make the space of gathering a meaningful place that is also tied to personal history.

In Michel Maffesoli's work, proxemics refers to the aesthetics of common feeling and collective experiences (Maffesoli 1996 [1988]: 123). For him, while encounters between people are increasingly abstract in everyday life, festivity facilitates concrete contacts with close-range proxemics. In doing so, cyclical festivities create extraordinary realities. For a short time, certain social norms can be overridden (Girard 1993 [1972]: 119) and situational social relationships — even with strangers - arise. Closeness and a special intimacy occur because of the shared extraordinary experiences and effervescent feelings. And this closeness is more intense in a state of relative anonymity in which people do not really know each other. To show how cyclical festivities create extraordinary realities and group solidarity, I will describe how festivities are arranged. Crucial here are the categories of time, space and body, reference points central to Durkheim's own framework for understanding collective effervescence in EFRL; these three dimensions constitute the tools of analysis and structure my argument.

\section{Elements of the Rituals: Time, Space and Body}

To understand how festivities can be organised, the temporal dimension must be considered; we have to bear in mind that people differentiate and divide time. As Durkheim states, "The division into days, weeks, months, years, etc. corresponds to the recurrence of rites, festivals, and public ceremonies at regular intervals. A calendar expresses the rhythm of collective activity while ensuring that regularity" (Durkheim 1995: $10 ; 1984$ [1895]). Time is organised collectively, contributing to people's orientations; it constitutes a framework for collectively coordinating activities. In this sense, time is always social. The calendar also divides time into periods characterised predominantly by the orientation to everyday life and others oriented to extraordinary events. The calendar determines and limits cyclical festivities such that the specific date and 
duration of the event is known and can be explicitly planned. Individuals need spare time for festivities, time during which they do not have any institutional obligations, fixed dates and deadlines. Leisure time means being free to enter alternate symbolic worlds, where ludic and experimental activities and attitudes are stressed (Turner 1982: 37).

Festivals as extraordinary realities are associated with the freedom from the rhythm and weight of everyday life. They are dominated by an alternative awareness of time, one that doesn't need clocks and time measurement. Festival time is time that is generous, connects participants and unites them in the here and now. Participants know that a festival is limited and this increases their exuberance. The limitedness of the festivity also reminds them of the finiteness of life (I will return to this point later). In this respect, a festival can be described as a state of "antistructure", with a "dissolution of normative social structure, with its role-sets, statuses" (Turner 1982: 28) and the order of everyday life. It is a kind of liminality, a term that Victor Turner uses following Arnold van Gennep. Liminality describes a state of transition, "a time outside time in which it is often permitted to play with the factors of sociocultural experience, to disengage what is mundanely connected" (Turner 1985: 236). This ludic element is central to liminality precisely because of the temporal limits surrounding it.

The spatial dimension of festival must also be considered in the consideration of festival. Festival organisation requires that people differentiate space; they need to denote one specific place as extraordinary for a certain time. This particular area must be known and accessible to all participants. It is prepared as exceptional: party tents, decorations, concession stands, mobile toilets, etc., mark the place as temporarily extraordinary. Such transformations constitute an enclave facilitating the transgression (and/or inversion) of certain social norms of everyday life and creates a limited (spatial) chaos with boundaries, keeping nonparticipants separate. Participants occupy this alternative world; they experience and perceive its altered state. The enclosed space produces proximity, which is important to the resulting shared mood and solidarity. The closeness intensifies collective feelings and ideas. As Durkheim puts it, "individuals, pressing close to one another, reaffirm in common their common sentiments" (1995: 429). Crucially, the greater the anonymity among people, the faster any initial embarrassment and/or selfconscious apprehension disappears. As collective bodily co-presence is the key precondition for membership in this extraordinary manifestation community, the body is the third dimension I will next describe.

The bodily dimension combines the two collective representations of time and space. The body is an object of creative styling during the 
festivity. Often, extraordinary clothes or costumes are worn to mark the reversal of daily routine. People do not only wear costumes or masquerades for carnival, but also for attending soccer games or public festivals. Carnivalesque clothing speaks its own language (Schiermer 2009), denoting the people as members of a transient community. Costumes and other forms of bodily expression are part of the social cement that holds them together. People are able to play different roles, to laugh about themselves and to interact more freely and easily. The costumes encourage them to act in different ways - this is part of "play" Roger Caillois calls "mimicry" (Caillois 2001 [1958]: 14ff.). People physically associated can participate in interaction rituals which help to negotiate the distance between the people, signifying the approval of extraordinary reality. In ritual, space, time and body are all connected to make sociality a sensual experience. Interaction rituals thus create spaces for the constitution of temporary communities (Soeffner 1992: 107). These ritualised communities involve the social actor's whole body in collective practices. The collective "we" - a collective state of being — and its corresponding collective representations, are created by the performative character of such rituals.

Durkheim stresses the connection between collective action and communion: "The individual minds can meet and commune only if they come outside, but they do this only by means of movements. It is the homogeneity of these movements that makes the group aware of itself and that, in consequence, makes it be" (Durkheim 1995: 232). For William H. McNeill, the social cohesion among any group that "keeps together in time"; moving, chanting, or singing rhythmically is called "muscular bonding" (McNeill 1995: 2). Collective muscular movements arouse euphoric fellow feelings among the participants. Durkheim already argues that human feelings are intensified when they are affirmed collectively (1995: 403). The body as a sign, a moving and feeling element in collective rites, must therefore be included in the sociological analysis of festivities as extraordinary realities.

Cyclical festivities as extraordinary realities create a we-identity and community physically expressed in the "here-and-now." This is why the categories of time, space and body are heuristically important for generating an adequate empirical description and analysis of carnivalesque frenzy. 


\section{Carnival in Germany's Rhineland}

Carnival in Germany's Rhineland is primarily a festival of joy and exuberance which has its peak immediately before Lent. The Rhineland is a loosely-defined region, which has become the general name for areas of Germany along the lower and middle Rhine. Cologne, Aachen, Bonn, Dusseldorf and Duisburg are some of the larger cities in this area. Traditionally, carnival season (called "the fifth season") opens on November 11 at 11 minutes past 11 and is interrupted by the Advent and Christmas season. The carnival season includes the official carnival with its stage shows (Sitzungen), where club members or invited guests perform dance, comedy and songs in costumes. It also includes street carnival, a week-long street festival, beginning on Fat Thursday and ending on Ash Wednesday, six days later. This is the part of carnival that takes place outside the festival halls and theatres. The carnival committees and clubs organise parades for the people, who go out in masquerade and enjoy the festival without paying any entrance fee. The highlight in carnival strongholds like Cologne, is Rose Monday when about 1.2 million spectators are gathered on the streets to see the Rose Monday parade. About a hundred carnival floats and over ten thousand active participants at the parade go at a crawl on a six and half kilometre route through the city center of Cologne. The participants on the floats throw out traditional sweets (Kamelle) and posies (Strüssjer), while the revellers on the streets are singing, laughing and shouting "Kamelle", "Strüssjer" or "Kölle Alaaf." The slogan and toast "Kölle Alaaf" (Cologne above all) can be heard on many occasions and has to be repeated three times while the right forearm is swung sideways on "Alaaf." This ritual expresses the goodwill of the participants. The slogan is meant to bless the city, carnival, the "Dreigestirn" (triumvirate), or others.

Since 1883, Cologne has granted three persons the titles of prince (Prinz), farmer (Bauer), and virgin (Jungfrau) for one year. In some other cities and surrounding regions, a carnival prince and princess, portrayed by a man and a woman, are chosen. The prince, as the personification of carnival, is the highest representative of the festivities and reigns over his "fool people" during carnival. In the long Rose Monday parade, his float is at the very end. The virgin and the farmer are on the second to last float, directly in front of the prince. Traditionally, the virgin is a man, symbolizing Cologne self-confidence. The farmer is the faithful and brave guardian of the city (Klauser 2007: 205). The triumvirate is one of the most significant symbols of the Cologne carnival. Holding one of these positions is very prestigious. 
Carnival Thursday (Fat Thursday or Women's Carnival) is another important date, when street carnival is opened at 11 minutes past 11 at Rhenish market places. The old and originally unorganised women's festival is based on the earlier pagan meaning of carnival. Traditionally, women take over control - they cut men's ties wherever they get hold of them and are allowed to kiss (bützen) every man who passes their way - but this reign lasts only for one day. People in masquerade dance, sing, drink alcohol and celebrate. The streets, pubs, and bars are filled to capacity on this day. Neither Fat Thursday nor Rose Monday are official holidays in Germany; nonetheless most public life comes to a standstill and shops close at around noon. The traditions and rites in Germany's Rhineland are dynamic and every spot has its own rules. I chose the Cologne region as a particular example because with its 480 carnival clubs, huge parade and 1.2 million spectators on Rose Monday, Cologne really represents Germany’s “carnival capital.”

\section{Methods}

In 2007 and 2008, I conducted an explorative-ethnographic study of Rhenish street carnival to investigate the social world of carnival particularly from the participants' perspective. The methods used were:

a) Participant observation of parades, carnival parties, gatherings on open squares and in pubs during the 2007 and 2008 street carnival. In addition, a participant observation of two carnival stage shows took place.

b) Ten narrative interviews, eight ad-hoc interviews and, numerous informal interviews with celebrating revellers and members of carnival club.

c) Collecting booklets from carnival sessions, local newspapers, municipal archival material, police operation reports, as well as lyrics of carnival hits.

The triangulation of data was assured not just by collecting different types of data but also through the methods of analysis. The interview material was hermeneutically interpreted in a reconstructive manner (Honer 1993), by aiming to explicate the interviewees' worlds of meaning and delve into deeper social realities. For the interpretation of the texts, the readings of other researchers were also included, compared and discussed. "This diminishes investigator bias and can be seen as a qualitative form of interreliability" (Mays and Pope 1995: 110). The observation protocols and a portion of the documents were analysed with the 
help of the ethnographic semantic analysis (also ethnoscience), building on the tradition of James P. Spradley's ethnotheory (Spradley 1980; Maeder 2002).

\section{The Life-World of Carnival; The Rites of a Rhenish Corroboree}

My analysis focuses on street carnival, taking place in public and in pubs, domains beyond the reach of mundane, institutionally controlled social order. By examining different rites and the perspectives of individual social actors who are involved in them, an eclectic portrait of Rhenish carnival as an organised form of collective effervescence, is created. I attend to ritually structured and limited time and space, as well as the imbrication of bodies in them, to generate a model of the life-world of the carnival.

\section{Carnival and its Temporal Reference Points}

Street carnival is a period that allows for escape from everyday temporal structures. Rhenish carnival as a festivity determined by the calendar, has fixed temporal reference points that are easily calculated for any given year by their dependence on Easter and the Lenten season. This means participation in street carnival can be planned over the long term. Many revellers celebrating carnival take their vacation days during this time to be free of work commitments, taking the opportunity to celebrate excessively. As Alf ${ }^{1}$ said, "Many dedicate their vacations for this. They really sacrifice their vacations for it. There are many people who use up two weeks of their vacation time" (Transcript 18: 543ff.). To celebrate carnival, there is a need for free time, especially considering that, for revellers, carnival is part of leisure activity and can be considered a "wasteful" use of social time. Alf, who owns a handicraft business, speaks of a sacrifice of time. This indicates that vacations and free time are valuable resources to him. To use them up during carnival indicates his deep connection to this annual festivity. The timing, which separates carnival from the rest of the year, guides participants to extraordinary realities. On closer inspection, the apparent disorder has a clear overall framework and a fixed program structure (Figure 1). The fixed temporal framing legitimises the day-long big party in the city centre in addition to the circumstance of public life standing still.

1. All interviews are anonymised. They were conducted in German and translated into English by the author. 


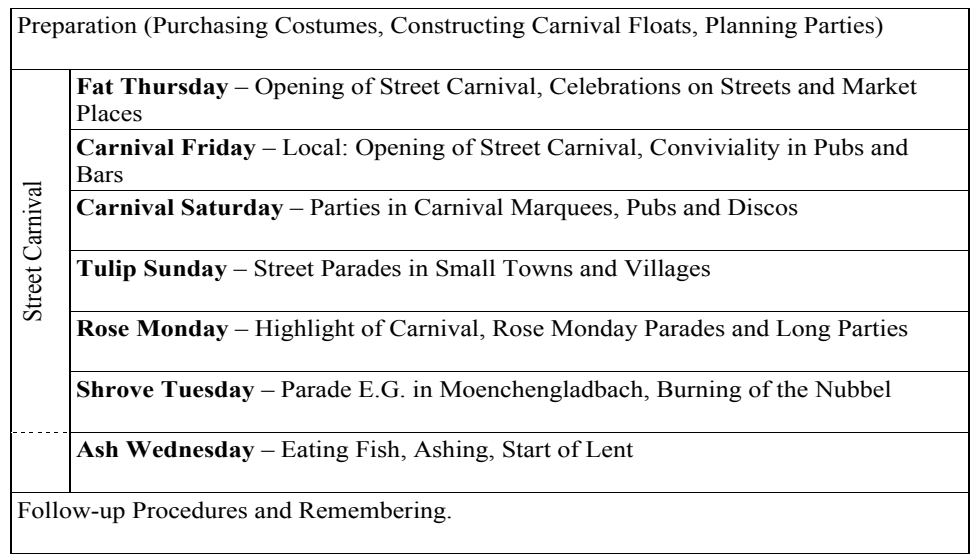

Figure 1: The Program Structure of Carnival

The six "crazy days" are accompanied by times of preparation and follow-up procedures. In Cologne, street carnival opens at 11 past 11 at the Alter Markt with countless celebrating spectators. In the evening and on the following days, there are fancy-dress balls and parties in carnival marquees and festival halls. Rose Monday with its parades and festivities can be called the highlight of carnival. On Shrove Tuesday, there are parades in some towns (e.g. in Moenchengladbach) and some events take place in preparation for the end of carnival, a sort of "farewell." On Ash Wednesday, Lent starts and the party is over until the next year and the beginning of a new carnival season. The preparation times and follow-up procedures stabilise the event's framework and ensure the continuity of celebration opportunities. The festival returns cyclically and, from this perspective, has an "eternal" element. The extraordinariness becomes an integral part of people's life-worlds because they spend their leisure time preparing and stabilising this festival each year.

Carnival, while "eternally" recurring in some respects, also functions as a reminder of finitude because the festivities are brief and transient. Philipp, a mayor of a Rhenish town, links the temporal limitation of being the Carnival Prince to the thought of the finite nature of everyday action on earth. "If I" $m$ Carnival Prince somewhere, then I am prince up to Ash Wednesday. This is a sign that everything we do - as human beings on this earth - is transient. And this is also reflected in the carnival" (Transcript 15: 475ff.) The temporal limitation of carnival reminds us that human existence is limited.

In this regard, the idea of "vanitas" is reflected in the carnival. The memento mori, the reminder of our mortality, has its symbolic equiva- 
lents in the figure of the fool who is associated with death, a figure synonymous with vanitas since the sixteenth century (Mezger 1984: 14). Also, many carnival musical hits make use of the finite-motif, e.g. "Su lang mer noch am Lääve sin" ("As long as we are still alive") of the dialect-singing band "Brings." On Shrove Tuesday, the Nubbel, a straw doll, which hangs above the pub doors during the "fifth season", is burned. At the end of the festivities, this doll, as a substitute "king of fools"2, is sacrificed (Girard 1993: 120). Shortly before midnight, the Nubbel is carried to his grave and burned (and with him all the sins of the carnival season, too). Nubbel's last journey is accompanied by the theatrical wailing of the people. The burning of the Nubbel as a symbol for the end of carnival has many similarities with funeral ritual, hinting at the end of life. It contains many elements of rites of separation, which Arnold van Gennep described as an example of "rites de passage" (2004: 146ff.)

In the Rhineland there are some more ceremonies of the same sort which can be interpreted as a "funeral of Carnival" (Frazer 1996: 363ff.) or even as the killing of the king of fools (Bataille 1991: 81f.) The signing of the cross with ashes on Ash Wednesday also symbolizes death and reminds people of their mortality. When a priest marks one's forehead with a cross, he says, "Remember, man, that thou art dust and unto dust thou shalt return" (Genesis 3: 19). This ritual introduces the Lenten period after the carnival time of immoderateness and hedonism. During carnival, the memento mori is interpreted as an invitation to pleasure and enjoyment. The popular Cologne band De Hoehner asks in a song "Wenn nicht jetzt, wann dann?" ("When, if not now?") and refers to the hereand-now for the pursuit of happiness and self-realisation. The individual takes time to think about his/her own mortality in only a few moments. But if we collectively remember this inescapable fact, life itself appears in a different frame, an excessive one. In this sense, carnival likewise stands for vitality and transience.

\section{Carnival and its Spatial Reference Points}

Carnival has clear spatial reference points marked by the carnival strongholds. Cologne as the most popular Rhenish stronghold, is admired by the people I interviewed, although only a few of them are natives. "Viva Colonia" - this is not just the title of a song by De Hoehner praising Cologne and enjoyment above all - it also expresses the mood of all those

2. This is not to be confused with Carnival Prince. 
I interviewed on Rose Monday 2008, in Cologne. When asked about why she was there, a thirty-one year old woman from Hesse replied "Because I absolutely love carnival and also because I absolutely love Cologne" (Transcript 1: 12). She mentions the love of carnival and the love of Cologne in one sentence, expressing the special relationship between Cologne and carnival, also found in the response of two young men: "Because we want to have fun and because Cologne is so great, because Cologne is the capital of carnival" (Transcript 5: 17f.) The interviewees are highly oriented toward the fun and adventures associated with carnival. For them, Cologne exactly represents the "capital of carnival" and "Cologne is number one" (Transcript 5: 28).

Now, valorising Cologne goes hand in hand with the devaluation of Dusseldorf - another carnival stronghold city on the other side of the Rhine River. The people of Dusseldorf and Cologne have had an ongoing enmity that dates back several centuries. The envy-ridden, competitive relationship between the two cities was originally based on the struggle for political influence and economic prosperity. Even today, this antipathy is the subject of carnival joking about who has the nicer parade or who celebrates the most beautiful carnival. The Rhine River is more than just a geographical line between the two cities; it is like a threshold manifesting the (now playful) opposition between Dusseldorf and Cologne. Additionally, this opposition itself generates a sense of community and belonging - having an "opponent" means that one has to rely on one's own community all the more, which shows how carnival can mean both unity and diversity at the same time.

The spatial dimension of carnival is also manifested in the decoration of public places, streets, shop windows, etc. During the six days of street carnival, an extraordinary spatial arrangement is created: beer tents, beer tables and benches, mobile toilets, music systems, etc., are procured. Streets become (transient) stages and the city centre is the place where the regime of mundane life is turned upside down. When carnival starts on Fat Thursday, with an opening ceremony traditionally launched by both the mayor of Cologne and the triumvirate at the Alter Markt, the common citizen publicly turns into a reveller. Variegated decorations transform mundane places, indicating that something extraordinary is about to "take place." Places temporarily become part of another reality and hence lose their reliability as reference points for people navigating about Cologne. Hubert, who grew up in the Rhineland, advises all who get lost in Cologne during carnival to look for the tips of the Cologne Cathedral to orient themselves. For guests of the city, the cathedral, located directly next to the main station, is an important landmark, "So even if you don't know Cologne, you only need to look, where the two 
spires are. If you go in this direction, you will have your orientation" (Transcript 10: 181ff.) Hubert points out that the cathedral is a reliable reference point during carnival.

Durkheim states that "every festival has certain characteristics of a religious ceremony, even if it is of purely secular origin" (1995: 386). One fieldwork situation illustrates something of this intermixture of the sacred and secular during festival time. On Tulip Sunday in 2008, I studied a carnival liturgy in a small town located on the Lower Rhine. The catholic liturgy started at ten o'clock in a crowded church, which was decorated with balloons and paper streamers. The church attendees were dressed up in colourful carnival costumes or traditional uniforms of the regional carnival club. Carnival songs and a parish with a clown were part of the mass which almost resembled a carnival stage show. In this situation the religious and the secular side of Carnival intermingle. Carnival has a religious dimension. It also, however, generates solidarity as a consequence of the organisation of festival space.

During street carnival, the central squares in the city play a crucial role. Whether they come from posh suburbs, the socially disadvantaged districts, or the student neighbourhoods, people come together in the centre of the city. Consequently, the social arrangement of the city temporarily changes. Social differences are substantially minimized, at least on the surface (Simmel 1989: 180). A sense of belonging arises due to the masses of people close together in one place (Bachtin 1969: 48). Rolf, a student who has been living in the Rhineland for a few years, describes the different look of the public squares during street carnival as follows: "It was totally crowded, every inch of space. Full of people, it was crowded everywhere" (Transcript 11/1: 516). The proximity and physical closeness of people was particularly noticeable on the train rides from the areas around Cologne to the city centre on Fat Thursday and Rose Monday. On these days, regional trains to Cologne are extremely crowded - overflowing with costumed revellers sharing drinks and snacks. Strangers toast each other, sing together and sway to and fro. Feelings of happy exuberance are intensified by the close proximity of people on the trains, suggesting that the bodily dimension plays a significant role as a medium and instrument of affect in the noisy and effervescent world of carnival, to which I now turn.

\section{Carnival and the Role of the Body}

Carnival is a somatic experience. The revellers' bodies are configured by costumes; extraordinary emotions and motions in collective rituals are as 
important as the alcoholic drinks that, in varying degrees, compromise bodily control.

The costume is an essential element of carnival: "Carnival is a feast of costumes. Costumes are simply part of it" (Transcript 11/1: 278ff.), a 30-year-old man in a Lord of the Rings costume said. To take another example, the dunce cap is an iconographic embodiment of carnival, signifying something of its extraordinary character. Costumes also indicate that one is a member of the carnival crowd, willing to participate, which in turn regulates integration into the community of revellers. The costume can also bridge differences and have a status-levelling effect (Simmel 1989: 226). Costumes express affiliation, but they also distinguish revellers from non-revellers. This distinction can also be experienced as a form of exclusion: "Without a costume, you don't feel you are part of the group" (Transcript 11/1: 317-318). Another young man expressed how it feels without a costume on Rose Monday as follows: "If you're not dressed in a costume, you somehow feel strange" (Transcript 4/1: 75-76).

The costume is a sign of changing roles. Temporarily, it allows one to be different and escape, at least for a short time, everyday role expectations, obligations and constraints. The costume is emancipatory, allowing one to act as "another person." The perception of one's body also changes in the process. Costumes stimulate playful behaviour, bringing back memories of childhood. Rolf tells of a man he saw on Rose Monday in Cologne, who had the figure of a Viking, but wore a light blue, child's playsuit costume: "Such a man, such a giant, could pass for a Viking, you know. But he had a pacifier and was completely in baby blue. Gosh! That's the blatantly obvious example: You're no longer yourself, you're a little boy, you're a baby" (Transcript 11/1: 417ff.). The giant becomes a baby, and Rolf appears genuinely thrilled about his observation like a little child. Whether dressed as cowboy or a fairy, costumed revellers indulge in all sorts of infantile games, clapping their hands to the beat of the music, participating in dance games, and singing songs with onomatopoetic words or nonsense texts. In this way, carnival satisfies a longing for childhood and for a simpler world.

The costume is not only individualising but can also homogenise people's behaviour. Members of a carnival club wear special uniforms. Each association has its own uniform, which differs in color and shape. In as much as the costumes celebrate the clubs of a town, they have a totemic function. They symbolize a classification system for different clans not dissimilar to the Australian clans described by Durkheim (1995: 141). This in turn provides something of a framework for gaining knowledge of the social organisation of the Rhineland. Painted people in 
costumes or in uniforms show that costuming can homogenize otherwise disparate individuals into recognisable groupings.

Carnival affects all sensory impressions, typically evoking intense feelings. Not knowing how to describe carnival, its meaning and history, a participant named Hubert notes that "Carnival is a feeling" and "Carnival? You have to see yourself!" (Transcript 10: 6, 11). Emotions and contiguous bodily experiences reinforce the impression made by carnival. The positive emotions of pleasure, joy and exuberance dominate. The absence of an express "goal" makes carnivalesque space freer, a reality more experimental in nature. But carnival is also a place of sentimentality that often results from the knowledge of its finiteness. The popular song "So ein Tag, so wunderschön wie heute, so ein Tag, der dürfte nie vergeh"n" ("Such a day as beautiful as it is today, such a day should never end"), is about the limitations of all pleasure, demonstrating that happiness and melancholy are both present in carnival.

Many songs that are played during carnival invite people to dance and move. As one participant put it, the people "are more spontaneous, going out with somebody or party with others and sway to and fro" (Transcript 1: 61ff.). The patterns of movement rely on the group as much as they constitute the corporeality of the group. Swaying to the music, for example, depends on collective motion and close physical contact with others. Dancing is connected with corporeal pleasures and desires that are present in carnival. A sense of community is created by collectively performed rituals, songs and dances, exuberant feelings and shared symbols. The bodies mutually relate to each other, and thus community is sensually felt.

Alcohol is also a part of carnival, increasing altered bodily perception. Drunkenness and alcohol are integrated and legitimised by the ritual context of carnival. The traditional and typical drink in the Rhineland is "Kölsch", a top-fermented lager. Collective drinking is legitimate throughout the day and, like a rite of passage, is part of entering carnivalesque reality. In this extraordinary world, people are on a firstname basis with each other and break away from everyday life and its role demands (Sulkunen 1981: 258). To be tipsy contributes to a cheery atmosphere. As a young reveller described it, carnival involves "nice people, many people, cheerful, a little bit drunk, the whole nine yards" (Transcript 6: 19-20). There are many different drinking games and rites, facilitating contacts and denoting both distinction and integration. By buying a round, revellers demonstrate their generosity and emphasise that drinking needs a community. While on the one hand, drunkenness is seen as normal - "of course a lot of alcohol is drunk in carnival" (Transcript 18: 1105) — on the other, it is also seen as a problem: "On 
Fat Thursday the young meet and get sloshed - come hell or high water" (Transcript 13/1: 101). This refers especially to adolescents engaged in excessive drinking, a behaviour that "has nothing to do with carnival" (Transcript 18: 1110). Normalisation on the one hand and problematisation on the other, are manifested in the ambivalent viewpoints regarding drinking during carnival. This popular discourse touches upon the entangled themes of sobriety and drunkenness and also upon the ambivalent issues of order and disorder.

\section{The Elementary Forms of Carnival}

Durkheim analyses "corroborees" as effervescent phases in which people think and act differently; they play an important role in collective and religious life. Carnival as an extraordinary world with altered temporal, spatial and bodily references, can be interpreted as a Rhenish corroboree. Costumes, masks and decorations change people's behaviour, self-perception and perception of others, as Durkheim well described; it "makes [them] think and act differently" (1995: 220). Such rites take people outside themselves, giving them a more vivid sense of their dual existence and nature (ibid.: 221). Durkheim reports on noisy chants, expressive dances, and on people violating the rules of sexual conduct. Are women, who kiss (bützen) men passing their way on Fat Thursday, not transgressing ordinary rules of sexual behaviour?

Durkheim notes that the close proximity of assembled individuals generates collective effervescence: "Once the individuals are gathered together, a sort of electricity is generated from their closeness and quickly launches them to an extraordinary height of exaltation. Every emotion expressed resonates without interference in consciousnesses that are wide open to external impressions" (ibid.: 218f.). In such contexts, feelings are no longer individual but collective, and people are taken far outside their ordinary conditions of life (Shilling 2005: 221f.). It is as though people were "transported into a special world entirely different from the one in which [they] ordinarily live" (Durkheim 1995: 220). This world is called the world of sacred things, where the religious idea is born (ibid.).

The division between the sacred and the profane, stressed by Durkheim (1995: 44), extending elements of Edward Tylor's major work Primitive Culture (Morrison 1995: 192), is one of the key elementary forms of religious life. Sacredness is constituted in peoples' practices, denoting relationships between profane and sacred existence in as much as sacred things, actions, places and persons are withdrawn from use 
in everyday life (Fields 1995: xlvi). Durkheim argues that beliefs, observable rites and specific social practices are part of the extraordinary and non-rational sacred state of being associated with the elementary forms of religious life. In moments of collective effervescence, collective feelings are produced, emphasizing the relevance of community in an affective way. The forces of the community are then sustained in the written symbols of the totem, which can designate an object, animal, or plant (Durkheim 1995: 223; Gane 1983). These symbols are socially transformative in a beneficent way in certain ritual contexts like carnival. Carnival produces images of community in people's minds, thus constituting the crucial link between individual and collective representations so central to the basis of the social bond in Durkheim's conception of it in EFRL. Rites and the resulting collective feelings and beliefs reinforce group solidarity, sustaining the imagined entity of community not only in "primitive" but also in modern societies, hence their being elementary. The images of community evoked by collective experiences are vitalizing and integrating.

\section{Discussion - Maffesoli, Neo-Tribalism and Carnival}

Michel Maffesoli, inspired in no small measure by Durkheim's conception of collective effervescence, identifies situations of collective effervescence as the core of sociality especially in "postmodern" societies. Postmodernity, for Maffesoli, is "the time of the tribes" (1996) with a constant interplay between masses, tribes, the persons which constitute tribes together with their forms of symbolisation (ibid.: 6). In his sociology, this kind of sociality is a characteristic of postmodernity with its focus on presence. Maffesoli's approach is similar to Durkheim's with his conception of the collective heritage or the soul of collectivity (ibid.: 15). Hedonism and the prevalence and play of symbols and images are features that Maffesoli describes in terms of the Dionysiac, involving non-productive, effervescent social activity (Maffesoli 1986 [1982]). Maffesoli's argument is that Dyonisiac practices are an increasing part of "postmodern" life and hence the world is being re-enchanted (Maffesoli 1979), after the modern, disenchanted period (Weber 1968 [1919]). Dionysus, the god of wine and revelry, stands for collective effervescence, where the individual and the collective conglomerate and genuinely commune, partaking of each other. The resulting bonds and sociality constitute a postmodern, neo-tribal society (Maffesoli 1996 [1988]).

As one finds in Durkheim's later sociology, Maffesoli also stresses the importance of rituals not only in religion, but as elemental compon- 
ents in all social spheres. For Maffesoli, rituals are always related to sociality (Maffesoli 1989: 11). Maffesoli, in the attempt to render an analysis of postmodern societies, thus shows that even today, Durkheim's concepts carry explanatory power. However, postmodern societies are best characterized in terms of "neotribalism" (s.a. Bauman 1990). Neotribes are imagined and labile conglomerations, in which people can find orgiastic experiences during collective events. In eruptions of sociality, tribes give free rein to emotions. Tribes in this context are seen to emerge from the consequences of individual decisions, and they are considered an essential element of the "postmodern."

In Durkheimian terms, ritual practices are the foundation of social life, and shared knowledge is created by the shared experience of these enacted practices. As he expresses it, "Religious representations are collective representations that express collective realities; rites are ways of acting that are generated only in the midst of assembled groups and whose purpose is to evoke, maintain, or recreate certain mental states of those groups" (Durkheim 1995: 9). On this basis, Durkheim locates the origin of the fundamental categories of human thought and reason, in the shared emotional experience of ritually produced moral forces generated within assembled groups (Rawls 2004: 10). He grounds his study of relations on an epistemology focused on social practices and how they are signified and communicated such that indices of them can be studied empirically. This is exactly what Maffesoli demands of an analysis of everyday life (1989: 11). Secularized culture in an era of globalisation is much more sacred than is often presumed. This in turn means recognising how the sacred and profane are continually (and differently) being constituted and reconstituted in embodied rituals in extraordinary spaces and time, something that the above analysis of Rhenish carnival has highlighted.

\section{Ambivalence: How Carnival Deals with a Key Feature of Contempor- ary Societies}

As mentioned above, carnival has an ambivalent nature. The festivity stresses individuality and collectivity at the same time. For instance, costuming is an individual and homogenising act, in exactly the postmodern way theorized by Maffesoli since individual choices are made about the costuming. However, the pleasure taken by individuals depends on community and the performance of every single reveller needs the assembled audience: carnival satisfies simultaneously the needs of eccentric, playful self-display and the needs of belonging. Carnival constructs a sense of unity and a chance for diversity manifesting the ambivalent interdependence of both. In this regard, carnival is characteristic of the 
elementary forms of social existence as understood by Durkheim. Carnival stands for vitality and transience alike, order and chaos, diversity and unity, happiness and melancholy. States of collective effervescence as we can find it in carnival can be described as moments of unity and warmth. These moments can be understood as a way of handling the tragic nature of human existence, reminiscient of Martin Heidegger's argument in Being and Time (1927; Tiryakian 1962). Creating sociality by revering the here-and-now is a vehicle for stabilizing the uncertainties and risks of human existence. During carnival people confront, simultaneously, both limitedness and infinity/eternity and find plural ways to manage the ambivalence of life.

In my view, carnival generates and manages ambivalence at the same time because it is a world that encourages individuals to face up to ambivalence. Dealing with ambiguities and uncertainties is held to be a key feature of contemporary societies (Junge 2000). Durkheim already understood the profoundly ambivalent consequences arising from the contrary tendencies of industrialisation, and assessed these transformations with both scepticism and hope (Junge 2008: 41). Ambivalence as a constitutively human experience, involves the feeling of being torn between two different and often mutually exclusive evaluation schemes for making sense of happenings in the social world (Junge 2008: 47). Crucially, deploying the concept of ambivalence makes it possible to go beyond conventional theoretical dichotomies. As Zygmunt Bauman argues (1991), ambivalence is an inescapable feature of social order since any classification excludes a third category. This third category presents a danger for any order since it provides a vantage point from which to question its legitimacy, demonstrating that other possible systems of classification could be possible. Indeed, ambivalence is constituted precisely by the exclusion of this third category. The study of carnival again and again refers to this "third" between two poles. Carnival overrides polarities for a few days and thus stimulates relaxation and relief.

\section{Conclusion}

This paper has explored the conditions and the possibility of collective effervescence through an examination of contemporary Rhenish carnival. Carnival is a cyclical event framed by rituals and customs. The three dimensions of time, space, and body were used to analyse the differential frame of carnival in order to develop a broader theoretical picture of the annual carnivalesque frenzy. It was shown how carnival collective 
effervescence relies on space and time limits determined by the environment which, in turn, both limits and renders ecstatic outbursts possible. By adopting ritual practices in close physical proximity and transforming corporeality, people establish neo-tribal transient communities. At the same time, however, the structural frame of collective effervescence constitutes conditions in which people confront the ambivalences of contemporary social existence. In this regard, Durkheim's and Maffesoli's critical sociological sensibilities serve as a stimulus for understanding how people accept and can overcome this ambivalence in a life-affirming way in the carnival context. Contemporary Carnival in the Rhineland provides ample evidence that there are extraordinary realities with effervescent, non-rational and sacred states that work to make everyday day life so much more worth living. In constituting feelings of belonging and categories of thought, as well as states of inherently embodied sociality, they indicate that sociological attention to events like Carnival is quite warranted. This is a task for which a contemporary engagement with Durkheim's sociology of religion is very well suited indeed.

\section{REFERENCES}

Bachtin, Michail. 1969. Literatur und Karneval. Zur Romantheorie und Lachkultur. München: Carl Hanser.

Bataille, Georges. 1991 [1976]. The Accursed Share. An Essay on General Economy. Volume II. The History of Eroticism \& Volume III. Sovereignty. New York: Zone Books.

Bauman, Zygmunt. 1990. Thinking Sociologically. Oxford: Basil Blackwell.

Bauman, Zygmunt. 1991. Modernity and Ambivalence. Ithaca: Cornell University Press.

Caillois, Roger. 2001 [1958]. Man, Play and Games. Urbana, Chicago: University of Illinois Press.

Durkheim, Émile. 1984 [1895]. Die Regeln der soziologischen Methode. Ed. and introduced by René König. Frankfurt am Main: Suhrkamp.

Durkheim, Émile. 1995 [1912]. The Elementary Forms of Religious Life. Translated and with an Introduction by Karen E. Fields. New York: The Free Press.

Durkheim, Émile. 2005. The dualism of human nature and its social conditions. In Durkheimian Studies 11(1):35-45.

Fields, Karen E. 1995. Translator's introduction. Religion as an eminently social thing. Pp. xvii-lxxiii in Émile Durkheim. 1995 [1912]. The Elementary Forms of Religious Life. New York: The Free Press. 
Frazer, James. 1996 [1922]. The Golden Bough. A Study in Magic and Religion. Abridged Edition. London: Penguin Books.

Gane, Mike. 1983. Durkheim: the sacred language. Economy and Society 12(1):1-47.

Gennep, Arnold van. 2004 [1960]. The Rites of Passage. London: Routledge.

Girard, René 1993 [1972]. Violence and the Sacred. Baltimore: The Johns Hopkins University Press.

Heidegger, Martin. 1986 [1927]. Sein und Zeit. Tübingen: Max Niemeyer.

Honer, Anne. 1993. Lebensweltliche Ethnographie. Ein explorativ-interpretativer Forschungsansatz am Beispiel von Heimwerker-Wissen. Wiesbaden: Deutscher UniversitätsVerlag.

Junge, Matthias. 2000. Ambivalente Gesellschaftlichkeit. Die Modernisierung der Vergesellschaftung und die Ordnungen der Ambivalenzbewältigung. Opladen: Leske + Budrich.

Junge, Matthias. 2008. Bauman on ambivalence - Fully acknowledging the ambiguity of ambivalence. Pp. 41-56 in Michael Hviid Jacobsen and Poul Poder, eds., The Sociology of Zygmunt Bauman: Challenges and Critique. Hampshire: Ashgate.

Klauser, Helene. 2007. Kölner Karneval zwischen Uniform und Lebensform. Münster: Waxmann.

Maeder, Christoph. 2002. Everyday Routine, Social Structure and Sociological Theory: Using Ethnographic Semantics for Research on Prisons. [26 passages]. Forum Qualitative Social Research. 3(1) Art. 15, http://nbn-resolving.de/urn:nbn:de:0114-fqs0201159 (access date: October 31, 2012).

Maffesoli, Michel. 1979. La conquête du présent. Pour une sociologie de la vie quotidienne. Paris: Presses universitaires de France.

Maffesoli, Michel. 1986 [1982]. Der Schatten des Dionysos. Zu einer Soziologie des Orgiasmus. Frankfurt am Main: Syndikat.

Maffesoli, Michel. 1987. Das gesellschaftliche Göttliche. Pp. 400-410 in Dietmar Kamper and Christoph Wulf, eds., Das Heilige: Seine Spur in der Moderne. Frankfurt am Main: Athenäum.

Maffesoli, Michel. 1989. The sociology of everyday life (epistemological elements) In Current Sociology. Journal of the International Sociological Association 37(1):1-16.

Maffesoli, Michel. 1996 [1988]. The Time of the Tribes. The Decline of Individualism in Mass Society. London: Sage.

Mays, Nicholas and Catherine Pope. 1995. Rigour and qualitative research. British Medical Journal 311:109-112.

McNeill, William H. 1995. Keeping Together in Time: Dance and Drill in Human History. Cambridge, Massachusetts: Harvard University Press. 
Mezger, Werner. 1984. Narren, Schellen und Marotten. Grundzüge einer Ideengeschichte des Narrentums. Pp. 1-35 in Dietz-Rüdiger Moser ed. Narren, Schellen und Marotten. Elf Beiträge zur Narrenidee. Remscheid: Verlag Ute Kierdorf.

Morrison, Ken. 1995. Marx, Durkheim, Weber: Formations of Modern Social Thought. London: Sage Publications.

Rawls, Anne Warfield. 2004. Epistemology and Practice. Durkheim's the Elementary Forms of Religious Life. Cambridge: Cambridge University Press.

Schiermer, Bjørn. 2009. Fashion Objects. Breaking up the Durkheimian cult. Distinktion: Scandinavian Journal of Social Theory 10(2):81-104.

Schwedt, Herbert. 1999. Der Prinz, der Rhein, der Karneval: Wege der bürgerlichen Fastnacht. Pp. 63-83 in Michael Matheus ed. Fastnacht/Karneval im europäischen Vergleich. Mainzer Vorträge 3. Stuttgart: Steiner.

Shilling, Chris. 2005. Embodiment, emotions, and the foundations of social order: Durkheim's enduring contribution. Pp. 211-238 in Jeffrey C. Alexander and Philip Smith, eds., The Cambridge Companion to Durkheim. Cambridge: Cambridge University Press.

Simmel, Georg. 1989. Über sociale Differenzierung. Sociologische und psychologische Untersuchungen. Pp. 109-295 in Georg Simmel, Gesamtausgabe: Band 2. Frankfurt am Main: Suhrkamp.

Soeffner, Hans-Georg. 1992. Die Ordnung der Rituale. Auslegung des Alltags 2. Frankfurt am Main: Suhrkamp.

Spradley, James P. 1980. Participant Observation. New York: Holt, Rinehart \& Winston.

Sulkunen, Pekka. 1981. Die Kosmopolitisierung und Kommerzialisierung des Alkoholgebrauchs - die neuen sozialen Bedeutungen des Alkohols. Pp. 256-261 in Gisela Völger and Karin von Welck, eds. Rausch und Realität. Drogen im Kulturvergleich. Band 1. Reinbek bei Hamburg: Rowohlt.

Tiryakian, Edward. A. 1962. Sociologism and Existentialism: Two perspectives on the individual and society. Englewood Cliffs: Prentice Hall.

Turner, Victor. 1982. From Ritual to Theatre: The Human Seriousness of Play. New York: PAJ Publications.

Turner, Victor. 1985. Images of anti-temporality: an essay in the anthropology of experience. Pp. 291-301 in Edith Turner, ed. On the Edge of the Bush: Anthropology as Experience. Tucson: University of Arizona Press.

Weber, Max. 1968 [1919]. Wissenschaft als Beruf. Pp. 582-613In Max Weber, Gesammelte Aufsätze zur Wissenschaftslehre. Tübingen: Mohr.

Yvonne Niekrenz is senior scientist in the Department of Sociology and Demography at the University of Rostock. Her research interests include the sociology 
of culture, the sociology of the body and the sociology of youth. Recent publications include: Rauschhafte Vergemeinschaftungen. Eine Studie zum rheinischen Straßenkarneval (Ecstatic Communal Relationships. A Study of Rhenish Street Carnival) and Jugend und Körper. Leibliche Erfahrungswelten (Youth and Body. Bodily Worlds of Experience) (co-edited with Matthias D. Witte).

http://www.wiwi.uni-rostock.de/soziologie/theorie/mitarbeiter/niekrenz/publikationen/

E-mail: yvonne.niekrenz@uni-rostock.de 
666 C) Canadian Journal of Sociology/Cahiers Canadiens de Sociologie 39(4) 2014 